\title{
Effects of anti-TNF-a treatment on lipid profile in rheumatic diseases: an analytical cohort study
}

\author{
Shadi Hassan ${ }^{1 \dagger}$, Uzi Milman ${ }^{2,3 \dagger}$, Joy Feld ${ }^{4}$, Lihi Eder ${ }^{5,6}$, Idit Lavi ${ }^{7}$, Shai Cohen ${ }^{1,3}$ and Devy Zisman ${ }^{3,4^{*}}$ (D)
}

\begin{abstract}
Background: The aim was to assess the influence of long-term treatment with tumor necrosis factor alpha (TNF-a) inhibitors on total cholesterol (TC), triglycerides (TG), low-density lipoprotein (LDL), high-density lipoprotein (HDL), and atherogenic index (Al) in rheumatoid arthritis (RA), psoriatic arthritis (PsA), and ankylosing spondylitis (AS) patients.

Methods: A retrospective cohort study was conducted on RA, PSA, and AS patients treated with TNF-a inhibitors for at least 270 days between 2001 and 2011. Levels of TC, TG, LDL, and HDL and the Al were compared with baseline values at $0-6,6-12,12-18$, and 18-24 months. Patients were further subdivided into three groups according to their HMG CoA reductase inhibitor (statin) treatment status in order to assess their effect on the results.

Results: The records of 311 patients (152 RA, 90 PsA, and 69 AS) were reviewed. TC and TG increased following treatment with TNF-a inhibitors, from $180.85 \pm 2.12 \mathrm{mg} / \mathrm{dl}$ and $116.00 \pm 3.55 \mathrm{mg} / \mathrm{dl}$ at baseline to $188.12 \pm 2.35 \mathrm{mg} / \mathrm{dl}$ $(p=0.02)$ and $132.02 \pm 4.63 \mathrm{mg} / \mathrm{dl}$ at $0-6$ months $(p<0.01)$, respectively, and to $184.88 \pm 2.09 \mathrm{mg} / \mathrm{dl}(p=0.02)$ and 129 . $36 \pm 4.32 \mathrm{mg} / \mathrm{dl}$ at $18-24$ months $(p<0.01)$, respectively. Al increased following treatment with TNF-a inhibitors, from $0.032 \pm 0.017$ at baseline to $0.004 \pm 0.019$ at $18-24$ months $(p<0.01)$. LDL decreased significantly in patients who were treated with statins before and during the entire study period, from $119.97 \pm 2.86 \mathrm{mg} / \mathrm{dl}$ at baseline to $104.02 \pm 3.57$ $\mathrm{mg} / \mathrm{dl}$ at $18-24$ months $(p<0.01)$, in contrast to an increase in LDL values in patients who did not receive statins during the study.
\end{abstract}

Conclusions: TNF-a inhibitor treatment was associated with a significant increase in TC and TG levels and the Al. Adding statins to the treatment was associated with a significant decrease in LDL levels.

Keywords: TNF-a inhibitors, Lipid profile, Rheumatoid arthritis, Ankylosing spondylitis, Psoriatic arthritis

\section{Background}

Atherosclerosis is a major cause of morbidity and mortality in systemic autoimmune diseases. Inflammation is central to the pathogenesis of atherosclerosis and is an important risk factor for vascular disease [1]. An increase in the atherogenic index (AI) is associated with an increase in the atherosclerosis process [2]. It is therefore important to treat cardiovascular risk factors, including dyslipidemia, in these patients.

\footnotetext{
* Correspondence: devyzisman@gmail.com

${ }^{\dagger}$ Equal contributors

${ }^{3}$ The Ruth and Bruce Rappoport Faculty of Medicine, Technion, Israel Institute of Technology, Haifa, Israel

${ }^{4}$ Department of Rheumatology, Carmel Medical Center, Haifa, Israel

Full list of author information is available at the end of the article
}

The influence of tumor necrosis factor alpha (TNF- $\alpha$ ) inhibitors on lipid profile [3-17] and AI [3, 5, 7-9, 11, $13,14,17]$ in patients with rheumatologic diseases has been examined in several studies (Table 1), with inconsistent results. In some studies TNF- $\alpha$ inhibitors promoted an atherogenic lipid profile, while in others there was no such effect. None of the studies assessed the timedependent impact of TNF- $\alpha$ inhibitors on the lipid profile of ankylosing spondylitis (AS), psoriatic arthritis (PsA), and rheumatoid arthritis (RA) patients as a group.

Our objective was to assess the influence of TNF- $\alpha$ inhibitors treatment on the lipid profile and the AI of patients with AS, PsA, and RA at various time points up to 2 years of treatment. 
Table 1 Literature on the influence of TNF-a inhibitors on lipid profile

\begin{tabular}{|c|c|c|c|c|c|c|c|c|c|c|c|c|}
\hline Author & $\begin{array}{l}\text { Publication } \\
\text { year }\end{array}$ & Place & $\begin{array}{l}\text { Follow up } \\
\text { (weeks) }\end{array}$ & $\begin{array}{l}\text { Patient } \\
\text { number }\end{array}$ & Disease & Drug & Research type & $\mathrm{TC}^{\mathrm{a}}$ & $\mathrm{TG}^{\mathrm{a}}$ & $L D L^{a}$ & $\mathrm{HDL}^{\mathrm{a}}$ & $\overline{A l^{2}}$ \\
\hline Popa et al. [4] & 2005 & The Netherlands & 2 & 33 & RA & ADA & Prospective & $\uparrow$ & $\leftrightarrow$ & $\leftrightarrow$ & $\uparrow$ & \\
\hline Vis et al. [6] & 2005 & The Netherlands & 6 & 69 & RA & INF & Prospective & $\uparrow$ & & & $\uparrow$ & \\
\hline Seriolo et al. [8] & 2006 & Italy & 24 & 34 & RA & $\begin{array}{l}\text { ETA, ADA, } \\
\text { INF }\end{array}$ & Prospective & $\uparrow$ & $\leftrightarrow$ & & $\uparrow$ & $\leftrightarrow$ \\
\hline Allanore et al. [10] & 2006 & France & 30 & 56 & RA & INF & Prospective & $\uparrow$ & & $\uparrow$ & $\uparrow$ & \\
\hline Popa et al. [9] & 2007 & The Netherlands & 52 & 55 & RA & INF & Prospective & $\uparrow$ & $\uparrow$ & $\leftrightarrow$ & $\leftrightarrow$ & $\uparrow$ \\
\hline Tam et al. [11] & 2007 & China & 14 & 19 & RA & INF & Prospective & $\uparrow$ & $\uparrow$ & $\uparrow$ & $\uparrow$ & $\leftrightarrow$ \\
\hline Peters et al. [13] & 2007 & The Netherlands & 48 & 80 & RA & INF & Prospective & $\leftrightarrow$ & $\leftrightarrow$ & & $\leftrightarrow$ & $\leftrightarrow$ \\
\hline Wijbrandts et al. [16] & 2009 & The Netherlands & 52 & 50 & RA & ADA & Prospective & $\leftrightarrow$ & $\leftrightarrow$ & $\leftrightarrow$ & $\leftrightarrow$ & \\
\hline Mathieu et al. [7] & 2010 & France & 14 & 34 & AS & $\begin{array}{l}\text { ETA, ADA, } \\
\text { INF }\end{array}$ & Prospective & $\uparrow$ & $\leftrightarrow$ & $\leftrightarrow$ & $\uparrow$ & $\leftrightarrow$ \\
\hline Castro et al. [12] & 2011 & Brazil & 3 & 15 & PA & INF & Prospective & $\leftrightarrow$ & $\uparrow$ & $\leftrightarrow$ & $\leftrightarrow$ & \\
\hline Daïen et al. [3] & 2012 & & $2-52$ & 13 articles & RA & $\begin{array}{l}\text { ETA, ADA, } \\
\text { INF }\end{array}$ & $\begin{array}{l}\text { Systematic review, } \\
\text { meta-analysis }\end{array}$ & $\uparrow$ & $\uparrow$ & $\leftrightarrow$ & $\uparrow$ & $\leftrightarrow$ \\
\hline Curtis et al. [5] & 2012 & United States & $\begin{array}{l}\text { Median }> \\
2 \text { years }\end{array}$ & 289 & RA & TNFi & Retrospective & $\uparrow$ & $\uparrow$ & $\uparrow$ & $\uparrow$ & $\leftrightarrow$ \\
\hline \multirow[t]{3}{*}{ Di Minno et al. [14] } & 2014 & & $2-52$ & 1707 & RA & TNFi & Meta-analysis & $\uparrow$ & $\uparrow$ & $\leftrightarrow$ & $\uparrow$ & $\leftrightarrow$ \\
\hline & & & & 30 articles & PsA & & & & & & & \\
\hline & & & & & AS & & & & & & & \\
\hline Souto et al. [15] & 2015 & & $12-24$ & 25 articles & RA & ADA, INF & $\begin{array}{l}\text { Systematic review, } \\
\text { meta-analysis }\end{array}$ & $\leftrightarrow$ & $\leftrightarrow$ & $\leftrightarrow$ & $\leftrightarrow$ & \\
\hline Chen et al. [25] & 2015 & Taiwan & 24 & 48 & RA & ETA, ADA & Prospective & $\leftrightarrow$ & $\leftrightarrow$ & $\leftrightarrow$ & $\uparrow$ & $\leftrightarrow$ \\
\hline \multirow[t]{3}{*}{ Present study } & 2016 & Israel & 104 & 311 & RA & TNFi & Retrospective & $\uparrow$ & $\uparrow$ & $\leftrightarrow$ & $\leftrightarrow$ & $\uparrow$ \\
\hline & & & & & PsA & & & & & & & \\
\hline & & & & & AS & & & & & & & \\
\hline
\end{tabular}

${ }^{a}$ Only significant changes $(p \leq 0.05)$ at the end of the follow-up period were included

$T N F-a$ tumor necrosis factor alpha, $T C$ total cholesterol, $T G$ triglycerides, $L D L$ low-density lipoprotein, $H D L$ high-density lipoprotein, $A l$, atherogenic index,

$R A$ rheumatoid arthritis, $A S$ ankylosing spondylitis, PSA psoriatic arthritis, ADA adalimumab, INF infliximab, ETA etanercept, TNFi TNF inhibitors

$\uparrow$ Increased, $\leftrightarrow$ Unchanged

\section{Methods}

\section{Study population}

A retrospective cohort analysis was conducted on the database of Clalit Health Services (CHS) in Haifa and Western Galilee districts in northern Israel. CHS is the biggest healthcare provider in Israel, with over 1 million members in this area (approximately $50 \%$ of the total population of the region). CHS maintains a comprehensive computerized database with continuous input from pharmaceutical, medical, laboratory, and administrative computerized operators. The CHS database and our study cohort were described in a previous study [18]. Briefly, the database for biological agents included in the Israeli 'health basket' contains diagnoses of specific rheumatic diseases as determined by a rheumatologist. The data are linked through a unique national identification number to the pharmaceutical, medical, and laboratory databases.

Medical charts of patients who met the following criteria were reviewed: minimum 18 years old; diagnosis under one of the codes-'rheumatoid arthritis', 'psoriatic arthritis', and 'ankylosing spondylitis' - and approval for biologic treatment included in the Israeli health basket; treated with TNF- $\alpha$ inhibitors between 2001 and 2011; began TNF- $\alpha$ inhibitors during the study period and were treated for at least 270 consecutive days; and had baseline lipid levels measured before starting treatment with TNF- $\alpha$ inhibitors and at least three lipid profile tests during the four time periods (0-6 months, 6-12 months, 12-18 months, and 18-24 months) (Fig. 1).

The following data were collected: demographics (age, gender); rheumatologist diagnosis (RA, PsA, AS); comorbidities (diabetes, hypertension, hyperlipidemia, ischemic heart disease); type and dates of pharmacy-dispensed medication (TNF- $\alpha$ inhibitors, steroids, disease-modifying anti-rheumatic drugs (DMARDs), HMG CoA reductase inhibitors (statins), fibrates); diabetes treatment; and laboratory tests results-lipid profile that included total cholesterol (TC), triglycerides (TG), low-density lipoprotein (LDL), and high-density lipoprotein (HDL). AI was calculated by the following formula: $\mathrm{AI}=\log$ (TG/ 


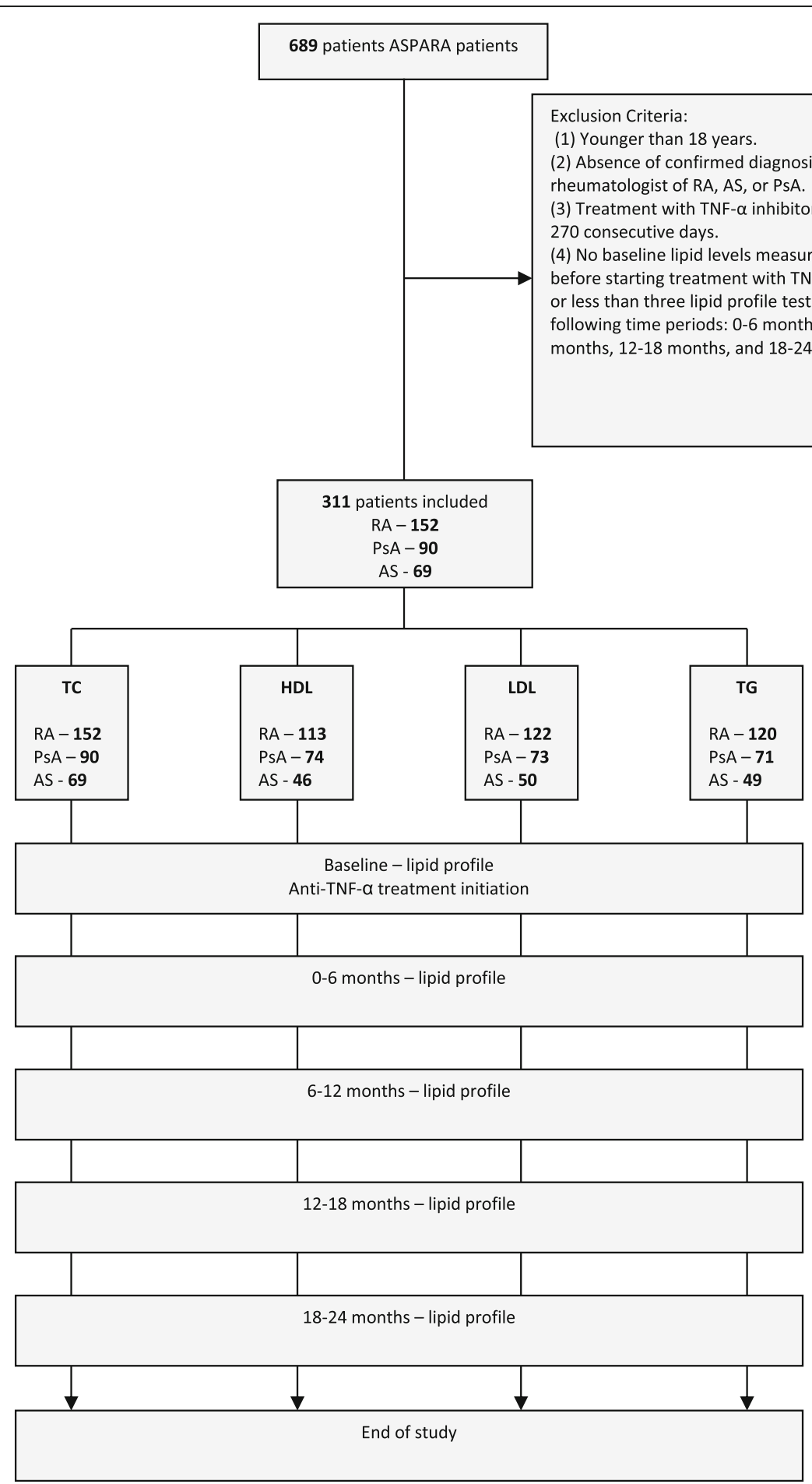

Fig. 1 Study flow. TNF-a tumor necrosis factor alpha, TC total cholesterol, TG triglycerides, LDL low-density lipoprotein, HDL high-density lipoprotein, $R A$ rheumatoid arthritis, AS ankylosing spondylitis, PSA psoriatic arthritis

HDL), with TG and HDL expressed in molar concentrations [2].

The patients were subdivided into three groups according to statin treatment:
Group 1 Patients not treated with statins.

Group 2 Patients who started statin therapy during the study period, after the initiation of treatment with TNF- $\alpha$ inhibitors. 
Group 3 Patients who were treated with statins prior to and during the entire study period.

Patients from Groups 2 and 3 were included only if the type and dose of statin did not change during the study period. Patients treated with fibrates, which are known to reduce TG levels [19], were excluded from the analysis in the TG group.

\section{Statistical methods}

Descriptive statistics are presented with continuous variables expressed as mean or median and standard deviation or standard error and categorical variables as frequencies and proportions. Comparisons of continuous patient characteristics among the three diagnostic groups (RA, PsA, AS) were performed by analysis of variance (ANOVA) or Kruskal-Wallis test, according to data distribution. Categorical variables were compared using the chi-square test.

The effect of TNF- $\alpha$ inhibitors therapy on lipid profile was assessed by comparing the levels of lipid particles at each time point with the baseline prior to treatment. Each lipid particle was analyzed in univariable and multivariable models, adjusted for the following study parameters: hyperlipidemia, statin treatment, steroid treatment, rheumatic diseases (RA, PsA, AS), obesity, smoking, diabetes, hypertension, ischemic heart disease, gender, and age.

Comparisons at various times were performed by repeated-measures mixed-model ANOVA. This procedure takes into account the intracorrelation of repeated measurements carried out on the same subject and does not exclude subjects with incomplete data at follow-up. Stratification analysis by statin use was employed in a multivariable model in patients treated concomitantly with a TNF- $\alpha$ inhibitor and statins after adjustment for hyperlipidemia, hypertension, obesity, gender, and age.

The analyses were conducted with the PASW (SPSS) 19 statistical package (PASW Software Statistic, SPSS, Chicago, IL, USA). All statistical tests were two-sided and statistical significance was considered $p \leq 0.05$.

\section{Results}

\section{Study population}

Of the 689 patients treated with TNF- $\alpha$ inhibitors between 2001 and 2011, 311 met the inclusion criteria: 152 RA patients, 90 PsA patients, and 69 AS patients. The mean age of RA and PsA patients was higher $(47.6 \pm 19.3$ and $50.2 \pm 13.4$ years, respectively) than that of AS patients $(39.7 \pm 15.2$ years, $p<0$. 01). As expected, there were more females in the RA group (74.3\%) than in the AS group $(36.0 \%, p<0.01)$. Corticosteroids were used more often in the RA group (58.7\%) than in the PsA and AS groups $(29.2 \%$ and $26.6 \%$, respectively, $p<0.01)$.
Diabetes, hyperlipidemia, and hypertension were more prevalent in the PsA group (19.0\%, $p=0.03 ; 52.2 \%, p=$ 0.02 ; and $40.0 \%, p=0.02$, respectively) than in the RA group $(11.2 \%, 37.5 \%$, and $36.2 \%$, respectively) and the AS group (1.4\%, $32.0 \%$, and $20.3 \%$, respectively). The incidence of ischemic heart disease did not differ significantly between the groups. Smoking was more prevalent in the AS group $(45.0 \%, p=0.02)$ than in the RA and PsA groups (26.3\% and $30.0 \%$, respectively). Baseline values of TC and LDL did not differ significantly between the groups. HDL and TG levels were significantly lower in patients with AS. Higher TG levels were found in PsA patients. There was no difference at baseline between the three groups in the percentage of patients treated with statins (Table 2). We excluded nine patients treated with fibrates from the TG group. These nine patients were treated with a constant dose of fibrates throughout the study and exhibited no significant changes in HDL and LDL values when TNF- $\alpha$ inhibitor was introduced; they were included in the TC, HDL, and LDL analysis.

\section{Lipid profile}

TC and TG levels increased following TNF- $\alpha$ inhibitor treatment, mainly during the first 6 months of treatment, and decreased thereafter but remained significantly higher than baseline at last follow-up (Table 3). LDL and HDL levels did not change significantly following introduction of TNF- $\alpha$ inhibitors.

The same pattern was found in the multivariate model after adjustment for hyperlipidemia, statin treatment, steroid treatment, rheumatic diseases (RA, PsA, AS), obesity, smoking, diabetes, hypertension, ischemic heart disease, gender, and age.

\section{Atherogenic index}

The AI increased significantly following TNF- $\alpha$ inhibitor treatment (Table 3). The same increase was found in the multivariate model after adjustment for hyperlipidemia, statin treatment, steroid treatment, rheumatic diseases (RA, PsA, AS), obesity, smoking, diabetes, hypertension, ischemic heart disease, gender, and age.

\section{Co-administration of TNF- $a$ inhibitors and statins}

The effect of the interaction between TNF- $\alpha$ inhibitors and statins on the various lipid parameters after adjustment for hyperlipidemia, hypertension, obesity, gender, and age reached statistical significance for LDL $(p<0.01)$, TC $(p=0.02)$, and TG $(p<0.01)$ values (Table 4$)$. No effect of the interaction was found in HDL values and therefore data were not analyzed further.

LDL levels rose higher than baseline values (103.13 \pm $3.68 \mathrm{mg} / \mathrm{dl}$ ) in patients treated with TNF- $\alpha$ inhibitors but not with statins, reaching statistical significance at $12-18$ months $(106.85 \pm 3.80 \mathrm{mg} / \mathrm{dl}, p=0.024)$ and 
Table 2 Baseline characteristics of patients with rheumatoid arthritis, psoriatic arthritis, and ankylosing spondylitis

\begin{tabular}{|c|c|c|c|c|c|}
\hline & & $\begin{array}{l}\text { Rheumatoid arthritis } \\
(n=152)\end{array}$ & $\begin{array}{l}\text { Psoriatic arthritis } \\
(n=90)\end{array}$ & $\begin{array}{l}\text { Ankylosing spondylitis } \\
(n=69)\end{array}$ & $p$ value \\
\hline \multirow[t]{2}{*}{ Age (years) } & & $47.6 \pm 19.3$ & $50.2 \pm 13.4$ & $39.7 \pm 15.2$ & $<0.0001$ \\
\hline & & 50.0 & 52.0 & 38 & \\
\hline \multirow[t]{8}{*}{ Baseline (mg/dl) } & $\mathrm{TC}^{\mathrm{a}, \mathrm{b}}$ & $180.6 \pm 37.6$ & $186.4 \pm 35.2$ & $174.3 \pm 38.9$ & NS \\
\hline & & 183.0 & 185.0 & 172.0 & \\
\hline & $\mathrm{HDL}^{\mathrm{a}, \mathrm{c}}$ & $53.92 \pm 15.67$ & $51.23 \pm 14.51$ & $46.40 \pm 13.31$ & 0.003 \\
\hline & & 52.08 & 48.25 & 43.38 & \\
\hline & $\mathrm{LDL}^{\mathrm{a}, \mathrm{d}}$ & $108.77 \pm 25.63$ & $114.43 \pm 22.31$ & $111.67 \pm 34.09$ & NS \\
\hline & & 110.70 & 117.14 & 109.39 & \\
\hline & $\mathrm{TG}^{\mathrm{a}, \mathrm{e}}$ & $111.35 \pm 53.44$ & $128.36 \pm 57.32$ & $109.49 \pm 53.87$ & 0.04 \\
\hline & & 96.46 & 119.00 & 106.00 & \\
\hline \multirow[t]{2}{*}{ Gender } & Male & $39(25.7)$ & $26(28.9)$ & $44(64.0)$ & $<0.0001$ \\
\hline & Female & $113(74.3)$ & $64(71.1)$ & $25(36.0)$ & \\
\hline \multirow[t]{2}{*}{ Statin treatment } & $\begin{array}{l}\text { Treated before and during treatment } \\
\text { with TNF-a inhibitors }\end{array}$ & $25(18.4)$ & $22(24.4)$ & $9(13.0)$ & NS \\
\hline & $\begin{array}{l}\text { Began treatment after beginning } \\
\text { TNF-a inhibitors treatment }\end{array}$ & $18(11.8)$ & $11(12.2)$ & $8(11.6)$ & \\
\hline \multirow[t]{2}{*}{ Medication } & Classical DMARDs ${ }^{f}$ & $93(62.0)$ & $35(39.3)$ & $20(31.3)$ & $<0.0001$ \\
\hline & Steroids & $88(58.7)$ & $26(29.2)$ & $17(26.6)$ & $<0.0001$ \\
\hline Smoking & Current or past & $40(26.3)$ & $27(30.0)$ & $31(44.9)$ & 0.02 \\
\hline Obesity & & $27(17.8)$ & $22(24.4)$ & $6(8.7)$ & 0.04 \\
\hline Hyperlipidemia & & $57(37.5)$ & $47(52.2)$ & $22(32.0)$ & 0.02 \\
\hline Diabetes & & $17(11.2)$ & $17(18.9)$ & $1(1.4)$ & 0.003 \\
\hline Hypertension & & $55(36.2)$ & $36(40.0)$ & $14(20.3)$ & 0.02 \\
\hline Ischemic heart disease & & $21(13.8)$ & $7(7.8)$ & $4(5.8)$ & NS \\
\hline
\end{tabular}

Data presented as standard deviation with median below, or as $n$ (\%)

${ }^{a}$ Because of missing values of lipid profile at various time points, the number of patients for each lipid profile test differed

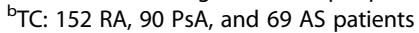

'HDL: 113 RA, 74 PsA, and 46 AS patients

dLDL: 122RA, 73 PsA, and 50 AS patients

'TG: 120 RA, 71 PsA, and 49 AS patients

${ }^{f}$ Classical DMARDs: leflunomide, azathioprine, cyclosporin, mercaptopurine, methotrexate, hydroxychloroquine, sulfasalazine

$T C$ total cholesterol, HDL high-density lipoprotein, $L D L$ low-density lipoprotein, TG, triglycerides, TNF-a tumor necrosis factor alpha, DMARD disease-modifying

anti-rheumatic drug, RA rheumatoid arthritis, AS ankylosing spondylitis, PsA psoriatic arthritis, NS not significant

$18-24$ months $(107.70 \pm 3.76 \mathrm{mg} / \mathrm{dl}, p=0.001) . \mathrm{LDL}$ in patients who began statins after the initiation of TNF- $\alpha$ inhibitors reached peak value at 6 months and 12-18 months. In contrast, LDL decreased significantly in patients who were treated with statins before starting TNF- $\alpha$ inhibitors and continued throughout the study: from $119.97 \pm 2.86 \mathrm{mg} / \mathrm{dl}$ at baseline to $107.84 \pm 3.96 \mathrm{mg} / \mathrm{dl}$ at $0-6$ months $(p<0.01), 108.26 \pm 4.07 \mathrm{mg} / \mathrm{dl}$ at $6-12$ months $(p<0.01), 101.85 \pm 3.57 \mathrm{mg} / \mathrm{dl}$ at $12-18$ months $(p<0.01)$, and $104.02 \pm 3.57 \mathrm{mg} / \mathrm{dl}$ at $18-24$ months $(p<$ 0.01) (Table 4).

TC increased in patients not treated with TNF- $\alpha$ inhibitors or statins, from $183.73 \pm 3.26 \mathrm{mg} / \mathrm{dl}$ at baseline to $188.63 \pm 3.42 \mathrm{mg} / \mathrm{dl}$ at $0-6$ months $(p<0.01)$ and $187.77 \pm 3.22 \mathrm{mg} / \mathrm{dl}$ at $12-18$ months $(p=0.03)$. In patients who began statins after the initiation of TNF- $\alpha$ inhibitors, TC increased from $188.96 \pm 8.92 \mathrm{mg} / \mathrm{dl}$ at baseline to $208.22 \pm 9.02 \mathrm{mg} / \mathrm{dl}$ at $0-6$ months $(p<0.01)$, $198.55 \pm 9.15 \mathrm{mg} / \mathrm{dl}$ at $12-18$ months $(p=0.04)$, and $199.38 \pm 8.46 \mathrm{mg} / \mathrm{dl}$ at $18-24$ months $(p=0.01)$. TC values in patients treated with statins before initiation of TNF- $\alpha$ inhibitors did not change significantly.

The same pattern was observed in TG values, which increased significantly in patients treated with TNF- $\alpha$ inhibitors but not statins, and in patients who began statins after the initiation of TNF- $\alpha$ inhibitors, but only in the first 6 months. TG values increased, but not significantly, in patients treated with statins before TNF- $\alpha$ inhibitor initiation and during the whole study period (Table 4). 
Table 3 Effects of TNF-a inhibitor treatment on lipid profile

\begin{tabular}{|c|c|c|c|c|c|c|}
\hline & & \multicolumn{5}{|l|}{ Time } \\
\hline & & $\begin{array}{l}\text { Baseline value before } \\
\text { treatment }\end{array}$ & 0-6 months & 6-12 months & $12-18$ months & 18-24 months \\
\hline \multirow[t]{3}{*}{ Total cholesterol (mg/dl) } & Mean \pm standard error & $180.85 \pm 2.12$ & $188.12 \pm 2.35$ & $183.80 \pm 2.14$ & $184.48 \pm 2.08$ & $184.88 \pm 2.09$ \\
\hline & $p$ value & & $<0.0001$ & NS & 0.030 & 0.015 \\
\hline & $\begin{array}{l}\text { Multivariate model } \\
p \text { value }\end{array}$ & & 0.018 & NS & 0.041 & 0.018 \\
\hline \multirow[t]{3}{*}{$\mathrm{HDL}(\mathrm{mg} / \mathrm{dl})$} & Mean \pm standard error & $51.8 \pm 1.07$ & $53.55 \pm 1.21$ & $51.06 \pm 1.13$ & $52.04 \pm 1.18$ & $52.05 \pm 1.18$ \\
\hline & $p$ value & & NS & NS & NS & NS \\
\hline & $\begin{array}{l}\text { Multivariate model }{ }^{a} \\
p \text { value }\end{array}$ & & NS & NS & NS & NS \\
\hline \multirow[t]{3}{*}{ LDL (mg/dl) } & Mean \pm standard error & $108.70 \pm 1.55$ & $109.00 \pm 1.92$ & $108.42 \pm 1.76$ & $108.54 \pm 1.75$ & $108.67 \pm 1.70$ \\
\hline & $p$ value & & NS & NS & NS & NS \\
\hline & $\begin{array}{l}\text { Multivariate model } \\
p \text { value }\end{array}$ & & NS & NS & NS & NS \\
\hline \multirow[t]{3}{*}{ Triglycerides (mg/dl) } & Mean \pm standard error & $116.00 \pm 3.55$ & $132.02 \pm 4.63$ & $124.47 \pm 3.95$ & $128.72 \pm 4.17$ & $129.36 \pm 4.32$ \\
\hline & $p$ value & & $<0.0001$ & 0.005 & $<0.0001$ & $<0.0001$ \\
\hline & $\begin{array}{l}\text { Multivariate model } \\
p \text { value }\end{array}$ & & $<0.0001$ & 0.004 & $<0.0001$ & $<0.0001$ \\
\hline \multirow[t]{3}{*}{ Atherogenic index (LogTG/HDL) } & Mean \pm standard error & $-0.032 \pm 0.017$ & $-0.001 \pm 0.02$ & $-0.01 \pm 0.019$ & $0.009 \pm 0.018$ & $0.004 \pm 0.019$ \\
\hline & $p$ value & & 0.005 & 0.043 & 0.001 & 0.003 \\
\hline & $\begin{array}{l}\text { Multivariate model } \\
p \text { value }\end{array}$ & & 0.007 & 0.04 & 0.001 & 0.004 \\
\hline
\end{tabular}

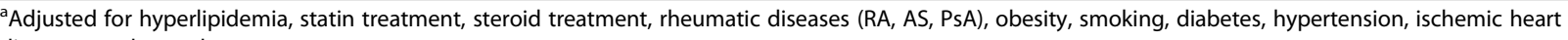
disease, gender, and age

TNF-a tumor necrosis factor alpha, HDL high-density lipoprotein, $L D L$ low-density lipoprotein, $T G$, triglycerides, NS not significant, RA rheumatoid arthritis, AS ankylosing spondylitis, PSA psoriatic arthritis

\section{Discussion}

The demographic and clinical characteristics of our cohort are consistent with those described in the literature. AS patients were young and most were males, while RA patients were older, needed more treatment with corticosteroids, and most were females [20, 21]. A large metaanalysis by Armstrong et al. in 2013 [22] showed an increased risk of metabolic syndrome in patients with psoriasis (odds ratio 2.26). According to our data, diabetes, hyperlipidemia, and hypertension were more prevalent in PsA patients than in RA and AS patients (Table 2).

TNF- $\alpha$ inhibitors revolutionized the treatment of inflammatory arthritic conditions [23, 24]. In our study, TNF- $\alpha$ inhibitors significantly increased the AI, TC, and TG levels without significantly changing LDL and HDL levels. They also significantly increased LDL, TC, and TG levels in patients who were not treated with statins during the study. This was in contrast to the decrease in LDL levels in patients who were treated with statins prior to initiation of TNF- $\alpha$ inhibitors and continued treatment throughout the study.

A comparison of our results with those reported in the literature must take into account the different study designs. The 15 studies that assessed the effects of TNF- $\alpha$ inhibitors on lipid profile (Table 1) [3-17] were of shorter duration, ranging from 2 to 30 weeks in nine studies $[4,6-8,10-12,15,17]$ and up to 52 weeks in six other studies $[3,5,9,13,14,16]$. Follow-up in our study was 104 weeks. We conducted our analysis on pooled data of rheumatic patients in the ASPARA cohort while most of the published studies analyzed a single disease: 12 studies of RA, one study of PsA, and one study of AS. Sample size also varied: $15-80$ patients in published studies $[4,6-13,16,17]$ compared with 311 patients in our cohort. Six of the studies were performed in patients treated with infliximab (INF) alone, and the rest included data on different types of TNF- $\alpha$ inhibitors such as INF, etanercept (ETA), and/or adalimumab (ADA) (11 of 15 studies) [3, 4, 6-13, 15, 17]. Our study was performed in patients treated with INF, ETA, or ADA.

Our finding of a significant increase in TC levels following TNF- $\alpha$ inhibitor treatment (Table 3) is in line with the results of 10 of the 15 studies mentioned [3-11, 14]. Six of the 15 studies also reported an increase in TG levels following TNF- $\alpha$ inhibitors $[3,5,9,11,12,14]$, similar to our findings, while the other nine showed no significant changes in TG levels. Nine of the 15 studies studied the effect of TNF$\alpha$ inhibitors on the AI $[3,5,7-9,11,13,14,17]$. Only one of them showed an increase in the AI [9], similar to our results, while the others did not demonstrate significant 
Table 4 Effects of TNF-a inhibitor treatment on lipid profile: stratification analysis by statin use

\begin{tabular}{|c|c|c|c|c|c|c|c|}
\hline & \multirow[b]{2}{*}{ Time period } & \multicolumn{2}{|l|}{ No statins } & \multicolumn{2}{|c|}{$\begin{array}{l}\text { Statin treatment begun after } \\
\text { initiating TNF-a inhibitor } \\
\text { treatment }\end{array}$} & \multicolumn{2}{|c|}{$\begin{array}{l}\text { Statin treatment begun before and } \\
\text { continued during TNF-a inhibitor } \\
\text { treatment }\end{array}$} \\
\hline & & Mean \pm standard error & $p$ value & Mean \pm standard error & $p$ value & Mean \pm standard error & $p$ value \\
\hline \multirow[t]{5}{*}{ Total cholesterol ${ }^{\mathrm{a}}(\mathrm{mg} / \mathrm{dl})$} & Reference & $183.73 \pm 3.26$ & & $188.96 \pm 8.92$ & & $182.04 \pm 5.65$ & \\
\hline & $0-6$ months & $188.63 \pm 3.42$ & 0.007 & $208.22 \pm 9.02$ & 0.005 & $188.78 \pm 5.73$ & NS \\
\hline & $6-12$ months & $185.20 \pm 3.29$ & NS & $197.92 \pm 8.74$ & NS & $184.05 \pm 5.60$ & NS \\
\hline & 12-18 months & $187.77 \pm 3.22$ & 0.03 & $198.55 \pm 9.15$ & 0.04 & $180.42 \pm 5.48$ & NS \\
\hline & 18-24 months & $188.62 \pm 3.34$ & NS & $199.38 \pm 8.46$ & 0.01 & $178.89 \pm 5.14$ & NS \\
\hline \multirow[t]{5}{*}{$\mathrm{LDL}^{\mathrm{a}}(\mathrm{mg} / \mathrm{dl})$} & Reference & $103.13 \pm 3.68$ & & $112.10 \pm 5.62$ & & $119.97 \pm 2.86$ & \\
\hline & $0-6$ months & $106.01 \pm 3.83$ & 0.057 & $123.42 \pm 7.62$ & 0.05 & $107.84 \pm 3.96$ & $<0.001$ \\
\hline & $6-12$ months & $105.63 \pm 3.80$ & NS & $115.35 \pm 7.05$ & NS & $108.26 \pm 4.07$ & $<0.001$ \\
\hline & 12-18 months & $106.85 \pm 3.80$ & 0.02 & $119.67 \pm 6.38$ & 0.03 & $101.85 \pm 3.57$ & $<0.001$ \\
\hline & 18-24 months & $107.70 \pm 3.76$ & 0.001 & $115.89 \pm 6.81$ & NS & $104.02 \pm 3.57$ & $<0.001$ \\
\hline \multirow[t]{5}{*}{ Triglycerides ${ }^{\mathrm{a}}$ (mg/dl) } & Reference & $119.41 \pm 9.75$ & & $179.31 \pm 19.96$ & & $142.14 \pm 9.89$ & \\
\hline & $0-6$ months & $134.33 \pm 10.24$ & $<0.001$ & $223.91 \pm 24.84$ & 0.002 & $147.33 \pm 10.67$ & NS \\
\hline & 6-12 months & $128.80 \pm 10.05$ & 0.02 & $186.09 \pm 20.47$ & NS & $145.81 \pm 10.15$ & NS \\
\hline & 12-18 months & $135.89 \pm 10.19$ & 0.001 & $181.31 \pm 20.98$ & NS & $149.60 \pm 10.16$ & NS \\
\hline & $18-24$ months & $135.99 \pm 10.20$ & $<0.001$ & $194.68 \pm 23.42$ & NS & $146.72 \pm 10.82$ & NS \\
\hline
\end{tabular}

${ }^{a}$ Adjusted for hyperlipidemia, hypertension, obesity, gender, and age

TNF-a tumor necrosis factor alpha, LDL low-density lipoprotein, NS not significant

changes of the AI. Concomitant treatment with statins, known to reduce TG, TC, LDL, and TNF- $\alpha$ levels [25, 26], could account for the lack of increase in TG levels and consequently the AI in those studies. Three studies that showed an increase in TG values included patients on drugs that affect the lipid profile, such as statins $[5,9,12]$; the studies that did not show significant changes in TG levels did not include them in their calculations $[4,6-8,10,13,15,16]$.

Our results showed no significant changes in the HDL and LDL values following TNF- $\alpha$ inhibitor treatment. The 10 studies from the literature $[3-8,10,11,14,17]$ (Table 1) that did report increased levels of HDL could be explained by the longer follow-up period in our study. Wijbrandts et al. [16] reported a significant increase in HDL levels after 16 weeks of ADA treatment, although the level returned to baseline by the end of the 52-week study. Similarly, HDL levels in our study increased during the first 24 weeks and returned to near baseline levels later, although none of these changes was statistically significant (Table 3). Like in our cohort, nine of the 15 studies that assessed the effects of TNF- $\alpha$ inhibitors on lipid profile $[3,4,7,9,12,14-17]$ showed no significant change in LDL level following TNF- $\alpha$ inhibitor treatment. Because this could be due to concomitant treatment with statins, which can lower LDL values $[25,26]$, we tested whether there was an interaction between TNF- $\alpha$ inhibitor and statin treatment that affected the lipid profile.
LDL, TG, and TC levels increased significantly in patients treated with TNF- $\alpha$ inhibitors but not with statins. LDL and TC levels also increased significantly in patients who began statin therapy during the study, while TG increased significantly only during the first 6 months in this group. LDL values in patients treated with statins before and during the entire study period decreased significantly throughout the study. Thus, concomitant treatment with TNF- $\alpha$ inhibitor and statins may protect against the expected increase in LDL, helping reduce the cardiovascular risk in rheumatic patients in addition to treating the inflammatory component.

To our knowledge, no other study has demonstrated the benefit to LDL levels of adding statin treatment to TNF- $\alpha$ inhibitors. A meta-analysis of 31 observational studies showed that the TNF- $\alpha$ gene is involved in the pathogenesis of the metabolic syndrome (the $308 \mathrm{~A}$ variant of this gene has been associated with elevated levels of insulin and blood pressure) [27]. Another study reported an association between polymorphisms of TNF- $\alpha$ (TNF- $\alpha$ G-238A) and LDL level [28]. These investigators also found that $T N F-\alpha-C-857 T-$ a polymorphism of the TNF- $\alpha$ gene promoter that increases transcription-is associated with increased LDL values and the formation of atherosclerotic carotid plaques in type 2 diabetes patients. Carriers of TNF- $\alpha-C-857 T$ had significantly increased LDL values compared with noncarriers. There was no difference in LDL values in patients who were not treated with statins regardless of the carrier state of 
$T N F-\alpha-C-857 T$. In contrast, carriers of TNF- $\alpha-C-857 T$ who were treated with statins had increased LDL levels compared with noncarriers [29]. In other words, there is a link between statin therapy, TNF- $\alpha$ activity level, and LDL. These findings, together with our results, call for further research into the impact on LDL levels of adding statin treatment in patients with increased activity levels of TNF- $\alpha$ (as in carriers who harbor the TNF- $\alpha-C-857 T$ polymorphism) compared with patients with low activity levels of TNF- $\alpha$ (such as those receiving TNF- $\alpha$ inhibitors).

There are some limitations in our study. In addition to being a retrospective and observational study without a control group, the study was conducted on a relatively small cohort of patients which included those who were taking various medications, including steroids and fibrates, and had illnesses such as diabetes that could affect lipid metabolism. We dealt with this limitation by constructing statistical models for each lipid profile parameter adjusted for possible confounders (Tables 3 and 4). Being a retrospective study, follow-up data were not complete on all subjects; nevertheless, in order to include them in the analyses, we used repeated measures with mixed models that allow for unbalanced data and calculated the intracorrelation of repeated measurements carried out on the same subject. We estimated the drug intake according to pharma dispensed prescriptions. It would be interesting to evaluate the effects of long-term anti-TNF therapy on carotid artery US findings and its association with lipid profiles changes in further studies.

\section{Conclusions}

The study documents the real-life, long-term follow-up and treatment of RA, PsA, and AS patients being treated with TNF- $\alpha$ inhibitors. We found that this treatment promotes an atherogenic lipid profile most pronounced in patients not treated by statins, evidenced by a significant increase in the AI, LDL, TC, and TG levels. Statin therapy before and during treatment with TNF- $\alpha$ inhibitors may protect against the expected rise in LDL values. While there were negative changes in the lipid profile under TNF- $\alpha$ inhibitor treatment, they were relatively small and not statistically significant, and their clinical significance is unclear.

Coronary disease is the main cause of death in rheumatic diseases and the importance of reducing cardiovascular risk factors, including dyslipidemia, in these patients cannot be overemphasized. Prospective studies on the long-term effects of TNF- $\alpha$ inhibitors on lipid profile, with and without statins, are required to assess the cardiovascular risk in these patients.

\section{Abbreviations}

ADA: Adalimumab; Al: Atherogenic index; AS: Ankylosing spondylitis; DMARD: Disease-modifying anti-rheumatic drug; ETA: Etanercept;

HDL: High-density lipoprotein; INF: Infliximab; LDL: Low-density lipoprotein;
PsA: Psoriatic arthritis; RA: Rheumatoid arthritis; TC: Total cholesterol; TG: Triglycerides; TNF-a: Tumor necrosis factor alpha

Acknowledgements

Not applicable

Funding

Not applicable

Availability of supporting data

Not applicable

Authors' contributions

$\mathrm{SH}$ participated in the study design and coordination, obtained data, participated in the statistical analysis, and wrote the manuscript. UM obtained data, participated in the study design, and drafted the manuscript. JF participated in analysis and interpretation of data and drafted the manuscript. LE participated in the design of the study and drafted the manuscript. IL participated in the design of the study, performed the statistical analysis, and drafted the manuscript. SC participated in the study design, and helped draft the manuscript. DZ conceived the study, participated in its design and coordination, and in analysis and interpretation of data, and drafted the manuscript. All authors read and approved the final manuscript.

Competing interests

The authors declare that they have no competing interests.

Consent for publication

Not applicable

Ethical approval and consent to participate

The study was approved by the ethics committee at Carmel Medical Center. Approval number CMC 06014722. The approval included exemption from individual consent.

Source of support

None declared

\section{Author details}

${ }^{1}$ Department of Internal Medicine, Carmel Medical Center, Haifa, Israel. ${ }^{2}$ Clinical Research Unit, Clalit Health Services, Haifa and Western Galilee District, Haifa, Israel. ${ }^{3}$ The Ruth and Bruce Rappoport Faculty of Medicine, Technion, Israel Institute of Technology, Haifa, Israel. ${ }^{4}$ Department of Rheumatology, Carmel Medical Center, Haifa, Israel. ${ }^{5}$ Women's College Research Institute, Women's College Hospital, Toronto, ON, Canada. ${ }^{6}$ Department of Medicine, University of Toronto, Toronto, ON, Canada. ${ }^{7}$ Department of Community Medicine and Epidemiology, Carmel Medical Center, Haifa, Israel.

Received: 3 August 2016 Accepted: 5 October 2016

Published online: 10 November 2016

\section{References}

1. Abou-Raya A, Abou-Raya S. Inflammation: a pivotal link between autoimmune diseases and atherosclerosis. Autoimmun Rev. 2006:5:331-7.

2. Shen S, Lu Y, Qi H, Li F, Shen Z, Wu L, Yang C, Wang L, Shui K, Wang Y, Qiang D, Yun J, Weng X. Association between ideal cardiovascular health and the atherogenic index of plasma. Med (Baltimore). 2016;95:e3866.

3. Daïen Cl, Duny Y, Barnetche T, Daurès JP, Combe B, Morel J. Effect of TNF inhibitors on lipid profile in rheumatoid arthritis: a systematic review with meta-analysis. Ann Rheum Dis. 2012;71:862-8.

4. Popa C, Netea MG, Radstake T, Van der Meer JW, Stalenhoef AF, van Riel PL, Barerra P. Influence of anti-tumour necrosis factor therapy on cardiovascular risk factors in patients with active rheumatoid arthritis. Ann Rheum Dis. 2005;64:303-5.

5. Curtis JR, John A, Baser O. Dyslipidemia and changes in lipid profiles associated with rheumatoid arthritis and initiation of anti-tumor necrosis factor therapy. Arthritis Care Res (Hoboken). 2012;64:1282-91.

6. Vis M, Nurmohamed MT, Wolbink G, Voskuyl AE, de Koning M, van de Stadt R, Twisk JW, Dijkmans BA, Lems WF. Short term effects of infliximab on the lipid profile in patients with rheumatoid arthritis. J Rheumatol. 2005;32:252-5. 
7. Mathieu S, Dubost JJ, Tournadre A, Malochet-Guinamand S, Ristori JM, Soubrier M. Effects of 14 weeks of TNF alpha blockade treatment on lipid profile in ankylosing spondylitis. Joint Bone Spine. 2010;77:50-2.

8. Seriolo B, Paolino S, Sulli A, Fasciolo D, Cutolo M. Effects of anti-TNF-alpha treatment on lipid profile in patients with active rheumatoid arthritis. Ann N Y Acad Sci. 2006:1069:414-9.

9. Popa C, van den Hoogen FH, Radstake TR, Netea MG, Eijsbouts AE, den Heijer M, van der Meer JW, van Riel PL, Stalenhoef AF, Barrera P. Modulation of lipoprotein plasma concentrations during long-term anti-TNF therapy in patients with active rheumatoid arthritis. Ann Rheum Dis. 2007:66:1503-7.

10. Allanore $Y$, Kahan A, Sellam J, Ekindjian OG, Borderie D. Effects of repeated infliximab therapy on serum lipid profile in patients with refractory rheumatoid arthritis. Clin Chim Acta. 2006:365:143-8.

11. Tam LS, Tomlinson B, Chu TT, Li TK, Li EK. Impact of TNF inhibition on insulin resistance and lipids levels in patients with rheumatoid arthritis. Clin Rheumatol. 2007;26:1495-8.

12. Castro KR, Aikawa NE, Saad CG, Moraes JC, Medeiros AC, Mota LM, Silva CA, Bonfá E, Carvalho JF. Infliximab induces increase in triglyceride levels in psoriatic arthritis patients. Clin Dev Immunol. 2011;2011:352686.

13. Peters MJ, Vis M, van Halm VP, Wolbink GJ, Voskuyl AE, Lems WF, Dijkmans BA, Twisk JW, de Koning MH, van de Stadt RJ, Nurmohamed MT. Changes in lipid profile during infliximab and corticosteroid treatment in rheumatoid arthritis. Ann Rheum Dis. 2007;66:958-61.

14. Di Minno MN, Ambrosino P, Peluso R, Di Minno A, Lupoli R, Dentali F, CaRRDs Study Group. Lipid profile changes in patients with rheumatic diseases receiving a treatment with TNF-a blockers: a meta-analysis of prospective studies. Ann Med. 2014;46:73-83.

15. Souto A, Salgado E, Maneiro JR, Mera A, Carmona L, Gómez-Reino JJ. Lipid profile changes in patients with chronic inflammatory arthritis treated with biologic agents and tofacitinib in randomized clinical trials: a systematic review and meta-analysis. Arthritis Rheumatol. 2015;67:117-27.

16. Wijbrandts CA, van Leuven SI, Boom HD, Gerlag DM, Stroes EG, Kastelein JJ, Tak PP. Sustained changes in lipid profile and macrophage migration inhibitory factor levels after anti-tumour necrosis factor therapy in rheumatoid arthritis. Ann Rheum Dis. 2009;68:1316-21.

17. Chen DY, Chen YM, Hsieh TY, Hsieh CW, Lin CC, Lan JL. Significant effects of biologic therapy on lipid profiles and insulin resistance in patients with rheumatoid arthritis. Arthritis Res Ther. 2015;17:52.

18. Zisman D, Haddad A, Hashoul S, Laor A, Bitterman H, Rosner I, Eder L, Balbir-Gurman A, Mader R, Milman U. Hospitalizations of patients treated with anti-tumor necrosis factor-a agents-a retrospective cohort analysis. J Rheumatol. 2013;40:16-22.

19. Koh KK, Quon MJ, Shin KC, Lim S, Lee Y, Sakuma I, Lee K, Han SH, Shin EK. Significant differential effects of omega-3 fatty acids and fenofibrate in patients with hypertriglyceridemia. Atherosclerosis. 2012;220:537-44

20. Liao KP, Karlson EW. Classification and epidemiology of rheumatoid arthritis. In: Hochberg MC, Silman AJ, Smolen JS, Weinblatt ME, Weisman MH, editors. Rheumatology. 6th ed. St. Louis: Mosby (Elsevier) Publishing; 2015. p. 691-7.

21. Rudwaleit M. Classification and epidemiology of spondyloarthritis. In: Hochberg MC, Silman AJ, Smolen JS, Weinblatt ME, Weisman MH, editors. Rheumatology. 6th ed. St. Louis: Mosby (Elsevier) Publishing; 2015. p. 941-5.

22. Armstrong AW, Harskamp CT, Armstrong EJ. Psoriasis and metabolic syndrome: a systematic review and meta-analysis of observational studies. J Am Acad Dermatol. 2013;68:654-62.

23. Dixon WG, Watson KD, Lunt M, Hyrich KL, British Society for Rheumatology Biologics Register Control Centre Consortium, British Society for Rheumatology Biologics Register, Silman AJ, Symmons DP. Reduction in the incidence of myocardial infarction in patients with rheumatoid arthritis who respond to anti-tumor necrosis factor alpha therapy: results from the British Society for Rheumatology Biologics Register. Arthritis Rheum. 2007;56:2905-12.

24. Jacobsson LT, Turesson C, Nilsson JA, Petersson IF, Lindqvist E, Saxne T, Geborek P. Treatment with TNF blockers and mortality risk in patients with rheumatoid arthritis. Ann Rheum Dis. 2007;66:670-5.

25. Chen $X$, Xun $K$, Chen L, Wang Y. TNF-alpha, a potent lipid metabolism regulator. Cell Biochem Funct. 2009;27:407-16

26. Palmer SC, Navaneethan SD, Craig JC, Johnson DW, Perkovic V, Hegbrant J, Strippoli GF. HMG CoA reductase inhibitors (statins) for kidney transplant recipients. Cochrane Database Syst Rev. 2014;31:5.

27. Sookoian SC, Gonzalez C, Pirola CJ. Meta-analysis on the G-308A tumor necrosis factor alpha gene variant and phenotypes associated with the metabolic syndrome. Obes Res. 2005;13:2122-31.
28. Shiau MY, Wu CY, Huang CN, Hu SW, Lin SJ, Chang YH. TNF-alpha polymorphisms and type 2 diabetes mellitus in Taiwanese patients. Tissue Antigens. 2003;61:393-7.

29. Takahashi T, Takahashi K, Yamashina M, Maesawa C, Kajiwara T, Taneichi H, Takebe N, Kaneko Y, Masuda T, Satoh J. Association of the TNF-\{alpha\}-C-857T polymorphism with resistance to the cholesterol-lowering effect of $\mathrm{HMG}-\mathrm{COA}$ reductase inhibitors in type 2 diabetic subjects. Diabetes Care. 2010;33:463-6.

\section{Submit your next manuscript to BioMed Central and we will help you at every step:}

- We accept pre-submission inquiries

- Our selector tool helps you to find the most relevant journal

- We provide round the clock customer support

- Convenient online submission

- Thorough peer review

- Inclusion in PubMed and all major indexing services

- Maximum visibility for your research

Submit your manuscript at www.biomedcentral.com/submit
) Biomed Central 